\title{
Analisa
}

\section{OTONOMI DAERAH DAN PENGELOLAAN SUMBER DAYA ALAM DI PROPINSI KALIMANTAN TIMUR (Studi Kasus Kewenangan Pengelolaan Kehutanan, Pertambangan dan Perkebunan) ${ }_{1}$}

\author{
Jauchar B. \\ Pengajar di Program Studi IImu Pemerintahan, Universitas Mulawarman \\ Jl. M uara M untai, Kampus Gn. Kelua, Samarinda - 75411 \\ Telp. 0541-7177701, Email: jkarimie@yahoo.com
}

\begin{abstract}
Natural resources management comes to the attention of the local government nowadays. This is due to the damage caused by the irresponsible natural resource management along this time. The provincial government's role in organizing and coordinating all aspects related to the natural resource management in the region is the key word of these issues. The East Kalimantan' strategic position as the region which has such potential natural resources has become the central point of the various natural resource management activities within the area. The emphasis of the regional autonomy at the district/city level has become a major obstacle for the provincial government in implementing the control functions of the natural resources management. The limited access to both the authority and the funding in the managerial sector which owned by the provincial government has caused the uncoordinated natural resource management policies in the region. Therefore, the provincial government needs to get a larger share in terms of managing the natural resource, so that a variety of natural resource management problems in the future can be minimize; especially in order to grasp the development of a sustainable natural resource.
\end{abstract}

Keywords : Policy, Authority, Management, Local Government

Intisari

Pengelolaan sumber daya alam menjadi perhatian pemerintah daerah dewasa ini. Hal tersebut disebabkan karena kerusakan yang ditimbulkan sebagai dampak pengelolaan sumber daya alam yang tidak memperhatikan keseimbangan lingkungan. Peran pemerintah propinsi dalam menyelenggarakan dan mengkoodinasikan semua aspek yang tekait dengan pengelolaan sumber daya alam di daerah menjadi kata kunci dari berbagai persoalan tersebut. Posisi strategis Propinsi Kalimantan Timur sebagai daerah dengan potensi sumber daya alam

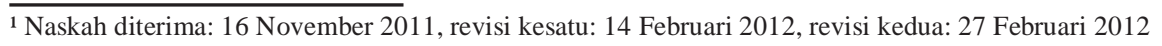


OTONOMI DAFRAH DAN PENGEL OLAAN SUMBER DAYA ALAM DI PROVINSI KALIMANTANTIMUR (STUDI KASUS KEWENANGAN PENGELOLAAN KEHUTANAN, PERTAMBANGAN DAN PERKEBUNAN)

Jauchar B.

yang begitu besar menjadi sentral dari berbagai aktifitas pengelolaan sumber daya alam di wilayahnya. Titik berat otonomi daerah pada level kabupaten/kota menjadi kendala utama bagi pemerintah propinsi dalam melaksanakan fungsi kontrol terhadap pengelolaan sumber daya alam di daerah ini. Keterbatasan akses baik dari sisi kewenangan maupun pendanaan dalam pengelolaan sumber daya alam menyebabkan tidak terkoodinasinya secara baik berbagai kebijakan pengelolaan sumber daya alam di wilayah Propinsi Kalimantan Timur. Pemerintah propinsi perlu mendapatkan porsi kewenangan yang lebih besar dalam hal pengelolaan sumber daya alam sehingga berbagai masalah pengelolaan sumber daya alam ke depan dapat diminimalisir. Hal tersebut terutama dalam upaya mewujudkan pembangunan sumber daya alam yang berkelanjutan.

Kata kunci : Kebijakan, Kewenangan, Pengelolaan, Pemerintah Daerah

\section{A. PENDAHULUAN}

Propinsi Kalimantan Timur merupakan daerah dengan potensi sumber daya alam yang melimpah. Kekayaan sumber daya alam tersebut menjadi modal dasar dalam mengelola dan membangun daerahnya. Meskipun tidak dapat dipungkiri bahwa dalam mengelola sumber daya alam tersebut terdapat berbagai persoalan yang menjadi dinamika dalam pelaksanaan pemerintahan. Persoalan sumberdaya alam menjadi sangat penting ketika dikaitkan dengan implementasi otonomi daerah. Betapa tidak, kemampuan pemerintah daerah dalam mengelola dan memanfaatkan sumber daya alam tersebut akan memberikan dampak bagi pengelolaan keuangan daerah. Potensi sumber daya alam yang dimiliki Propinsi Kalimantan Timur menjadi hal strategis ketika mampu dikelola dan dikembangkan secara maksimal dalam menunjang roda pemerintahan dan pembangunan wilayah tersebut.

Kewenangan pengelolaan sumberdaya alam yang selama ini terkesan mengabaikan koordinasi diantara level pemerintahan menjadi fakta empirik bagi pemerintah dalam mewujudkan pembangunan lingkungan yang berkelanjutan. Peran pemerintah propinsi yang selama ini diharapkan menjadi sentral dalam pengelolaan sumberdaya alam di daerah belum mampu diwujudkan sesuai dengan harapan. Kerjasama antara pemerintah dengan pemangku kepentingan di daerah belum terwujud sebagaimana mestinya. Upaya pelibatan stakeholders sebagaimana yang diamanahkan dalam UndangUndang Dasar 1945 menyebutkan bahwa negara melakukan penguasaan terhadap sumberdaya alam (bumi dan air beserta isinya) untuk sebesar-besar kemakmuran rakyat perlu mendapatkan perhatian yang lebih dari pemerintah propinsi. Keterbatasan kewenangan yang dimiliki pemerintah propinsi memerlukan kerja keras guna mendapatkan kewenangan yang lebih besar dalam pengelolaan sumberdaya alam diwilayahnya. Kewenangan pengelolaan sumber daya alam yang dimiliki oleh pemerintah propinsi perlu 
disinergikan dengan stakeholders yang ada di daerah. Keterlibatan semua pemangku kepentingan dalam pengelolaan sumber daya alam menjadi begitu penting seiring dengan implementasi otonomi daerah dalam satu dasawarsa terakhir.

$$
\text { Implementasi asas }
$$

desentralisasi yang menekankan pada otonomi daerah seluas-luasnya dan bertanggung jawab menuntut peran dan kreatifitas dari pemerintah daerah dalam mengelola dan mengembangkan daerahnya. Kewenangan yang dimiliki oleh pemerintah propinsi dalam pengelolaan sumber daya alam perlu untuk dimaksimalkan dengan tetap memperhatikan pola koordinasi dan luasnya kewenangan yang dimiliki. Sehubungan dengan hal tersebut, pemerintah Propinsi Kalimantan Timur memiliki peran yang sangat strategis dalam rangka pengelolaan sumberdaya alam yang dimilikinya. Dalam rangka memaksimalkan potensu sumber daya alam yang dimiliki maka diperlukan upaya serius dari pemerintah propinsi khususnya SKPD dalam lingkup propinsi yang terkait dengan pengelolaan sumberdaya alam untuk berbuat tidak hanya sebagai pelaksana, tetapi juga sekaligus sebagai perumus kebijakan (Santoso,2003). Peran pemerintah propinsi dalam mengelola sumber daya alam tidak dapat dipisahkan dengan Rencana Tata Ruang Wilayah (RTRWP) sebagai dasar dalam mengelola dan mengembangkan wilayahnya sehingga tetap terjaga kelestarian dan sesuai dengan peruntukkannya.

Rencana Tata Ruang Wilayah Propinsi (RTRWP) sebagai salah satu instrumen yang memberi arahan kepada pemerintah daerah untuk melakukan penentuan peruntukan ruang secara tepat harus menjadi acuan utama dalam pengelolaan sumberdaya alam di daerah agar tercipta pemanfaatan wilayah sesuai dengan yang diharapkan. Hal tersebut senada dengan arah pelaksanaan otonomi daerah dimana peran pemerintah daerah (kabupaten/kota dan propinsi) menjadi sangat strategis. Amanat Undang-Undang No 32 Tahun 2004 Tentang Pemerintah Daerah jelas memberikan kewenangan kepada daerah meskipun belum sepenuhnya dalam pengelolaan sumber daya alam di daerah. Sejumlah penandatanganan kontrak kerja pengelolaan hutan, tambang dan sebagainya merupakan wilayah pemerintah daerah dengan kapasitas sebagai penentu kebijakan yang nantinya secara otomatis mengubah keadaan sumberdaya alam yang kesemuanya itu memberikan tekanan baru bagi kerusakan lingkungan (Santoso,2003). Dampak yang nyata dari pengelolaan sumber daya alam yang tidak memperhatikan kondisi lingkungan berakibat pada rusaknya ekosistem lingkungan tersebut. Dengan demikian, diperlukan adanya suatu perangkat peraturan perundangundangan yang secara tegas mengatur pengelolaan sumber daya alam di daerah. Dalam pengaturan mengenai tata kelola sumber daya alam didaerah tentunya juga harus melibatkan stakeholders yang memiliki kewajiban dan tanggung jawab terhadap sumber daya alam tersebut. Sinergitas antara peraturan perundang-undangan dan RTRWP Kalimantan Timur dalam pengelolaan sumberdaya alam harusnya menjadi perhatian dari pemerintah propinsi guna mewujudkan 
pengelolaan sumber daya alam yang berkelanjutan. Pemerintah propinsi sebagai pelaksana asas dekonsentrasi dituntut untuk mampu menerjemahkan dan mengimplementasikan kebijakan pemerintah pusat terkait dengan pengelolaan sumberdaya alam. Hal tersebut terkait dengan fungsi koordinasi antar daerah dalam mengelola dan memanfaatkan sumber daya yang dimilikinya. Selain itu, keterpaduan kebijakan antara pemerintah propinsi dengan pemerintah kabupaten/kota dalam pengelolaan sumberdaya alam di daerah mutlak diperlukan mengingat tidak semua hak pengelolaan hanya dimiliki oleh pemerintah propinsi. Terdapat beberapa kewenangan pengelolaan sumberdaya alam yang diserahkan kepada pemerintah kabupaten/kota yang menempatkan pemerintah propinsi hanya sebagai pemberi stempel atau pihak yang menyetujui tanpa memiliki kewenangan membatalkan atau menolak kebijakan tersebut.

Kewenangan pengelolaan sumber daya alam yang lebih besar pada pemerintah kabupaten/kota menempatkan pemerintah propinsi sebagai unsur yang besar secara administratif tepi sangat lemah dalam hal kewenangan. Perdebatan mengenai kewenangan pengelolaan sumber daya alam di Propinsi Kalimantan Timur menjadi isu sentral karena dengan potensi sumber daya alam yang dimiliki ternyata tidak berbanding lurus dengan tingkat kesejahteraan masyarakatnya. Kondisi faktual yang terjadi di Propinsi Kalimantan Timur menunjukkan bahwa dampak nyata dari pengelolaan sumber daya alam diwilayah ini adalah terganggunya ekosisitem lingkungan. Kerusakan lingkungan dalam satu dasawarsa terakhir telah memberikan dampak pada kehidupan masyarakatnya. Pemerintah propinsi sebagai pemegang kewenangan dalam hal koordinasi antar wilayah dalam pengelolaan sumber daya alam belum menunjukkan eksistensinya.

Sementara kerusakan lingkungan sebagai dampak pengelolaan sumber daya alam tersebut semakin nyata. Hal tersebut senada dengan paham ekosentris sebagai salah satu bentuk pendekatan pengelolaan sumber daya alam. Sebagai contoh, jika terjadi pengrusakan terhadap hutan akibat penebangan dan penambangan yang tidak mengindahkan keseimbangan ekosistem, maka untuk melakukan proses keseimbangan kembali, banjir akan terjadi pada wilayah-wilayah yang terganggu keseimbangannya. Paham ekosentrisme ( the deep ecology) lebih jauh melihat bahwa semestinya terbangun suatu hubungan yang lebih mendalam antara manusia dengan lingkungan. Terdapat dua gagasan utama dari pendekatan deep ecology dalam pengelolaan lingkungan, pertama; manusia dan kepentingannya bukan lagi ukuran bagi sesuatu yang lain. Ia tidak hanya melihat spesies manusia saja, tetapi juga memandang spesies lain. Pernyataan ini sekaligus juga menunjukkan bahwa ekosentrisme tidak setuju dengan nilai denominatif yang dibawa oleh antroposentrisme. Kedua, pandangan tentang lingkungan harus bersifat praktis. Artinya, etika ini menunutt suatu pemahaman baru tentang relasi yang etis dalam semesta (terutama antara manusia dengan makhluk yang lain) disertai prinsip- 
prinsip yang bisa diterjemahkan dalam gerakan lingkungan (Dwi Susilo, 2008;113-114.

Berdasarkan uraian yang telah dikemukakan tentang posisi pemerintah Propinsi Kalimantan Timur dalam pengelolaan sumber daya alam diwilayahnya. Maka penulis akan menkaji lebih mendalam mengenai kewenangan pengelolaan sumber daya alam yang dimiliki oleh pemerintah propinsi sebagaimana yang diatur dalam dalam peraturan perundangundangan dengan menfokuskan diri pada pengelolaan hutan, tambang dan perkebunan serta upaya-upaya apa saja yang dilaksanakan dalam mengoptimalisakan pengelolaan sumber daya alam tersebut?

\section{B. OTONOMI DAERAH DAN PENGELOLAAN SUMBER DAYAALAM \\ 1. Kajian Kepustakaan}

Pengelolaan sumber daya alam di era otonomi daerah menjadi salah satu perhatian dari birokrasi dan akademisi. Hal tersebut disebabkan karena kerusakan lingkungan yang ditimbulkan sebagai dampak dari pengelolaan sumber daya alam yang tidak memperhatikan keseimbangan ekosistem lingkungan telah dirasakan masyarakat secara umum. Akibat kerusakan lingkungan tersebut terlihat bencana alam seperti longsor, banjir, dan perubahan iklim yang semakin terasa dampaknya. Kartodiharjo (2006) melihat pengelolaan sumber daya alam di era otonomi daerah dalam dua perspektif yaitu :, perkembangan kebijakan dan implikasi bagi hubungan antar lembaga. Pertama, dalam perkembangan kebijakan disebutkan bahwa kebijakan pengelolaan sumber daya alam telah mulai mendaptak perhatian. Hal tersebut terlihat dari (a). RUU PSDA dan Peraturan Pemerintah Nomor 25 Tahun 2000 Tentang Kewenangan Pemerintah dan Pemerintah daerah. Dalam RUU PSDA tersebut perlu untuk memperhatikan pendekatan sektor dalam pengelolaan SDA, transformasi institusi yang terlibat serta posisi inestasi dalam pengelolaan SDA. (b). Penilaian kinerja kelembagaan daerah yang telah menunjukkan munculnya pola pola pengalolaan SDA yang memperhatikan keseimbangan dan kesinambungan pengelolaan SDA. Kedua, implikasi pengelolaan SDA terhadap hubungan antar lembaga yaitu kurangnya koordinasi dalam pengelolaan SDA sehingga ukuran kinerja antar lembaga yang berbeda dan tidak diperhitungkannya secara matang mengenai dampak jangka panjang dari pengelolaan SDA tersebut. Hubungan antar lembaga dan seluruh stakeholders pemerintahan juga muncul sebagai dampak dari pengelolaan SDA di era otonomi daerah. Yasmi dkk. (2005) menyatakan bahwa imbas dari pengelolaan SDA khususnya sektor kehutanan yang mengikuti kecenderungan yang terjadi di tingkat nasional yang lebih mengutamakan ekstraksi kayu daripada pengelolaan hutan lestari. Pengelolaan yang cenderung ekspolitatif tersebut muncul karena lemahnya perangkat hukum yang mengatur perlindungan terhadap kepentingan masyarakat setempat, hal tersebut mengakibatkan munculnya potensi konflik antar elit dalam pengelolaan sektor kehutanan yang dapat berdampak luas pada masyarakat dan jalannya roda pemerintahan. Selain potensi konflik 
yang muncul sebagai akibat dari pengelolaan kehutanan, sisi baiknya adalah peningkatan PAD dari beberapa kabupaten sebagai imbas dari pengelolaan sektor kehutanan di Kalimantan Barat. Padangan berikutnya yang terkait dengan otonomi daerah \& pengelolaan sumber daya alam dapat dilihat dari hasil penelitian Sabar (2009) yang melihat pengelolaan SDA dari perspektif dukungan peraturan perundang-undangan di daerah, penguatan kelembagaan di daerah, peningkatan koordinasi antar lembaga dalam pengelolaan SDA. Dalam hasil penelitiannya disebutkan bahwa peraturan perundangan yang berkaitan dengan pengelolaan sumber daya alam sudah cukup memadai, namun demikian didalam pelaksanaanya, termasuk dalam pengawasan, pelaksanaannya perlu mendapatkan perhatian yang sungguh-sungguh. Hal ini sangat terkait dengan niat baik pemerintah termasuk pemerintah daerah, masyarakat dan pihak-pihak yang berkepentingan untuk mengelola sumber daya alam dengan sebaikbaiknya agar prinsip pembangunan berkelanjutan berwawasan lingkungan dapat terselenggara dengan baik. Oleh karena pembangunan pada dasarnya untuk kesejahteraan masyarakat, maka aspirasi dari masyarakat perlu didengar dan program-program kegiatan pembangunan betul-betul yang menyentuh kepentingan masyarakat.

Kajian tentang otonomi daerah dan pengelolaan SDA menunjukkan bahwa arah kebijakan pengelolaan sumberdaya alam di era otonomi daerah ditujukan pada pengembangan kapasitas kelembagaan pemerintah di daerah sehingga hal tersebut benar sesuai dengan cita-cita bangsa. Dalam tulisan ini penulis akan lebih menekankan untuk melihat dan mengkritisi kewenangan pengelolaan sumber daya alam dilevel propinsi yang merupakan wakil pemerintah pusat yang ada di daerah. Upaya untuk mensinergikan pengelolaan SDA di derah tentunya hanya akan dapat berjalan sesuai dengan yang diharapkan jika semua stakeholders yang ada dapat menjalankan tugas dan fungsinya serta porsi kewenangan yang seimbang dengan tugas dan fungsi tersebut.

\section{Konsep Otonomi Daerah \& Pengelolaan Sumber Daya Alam} Implementasi otonomi daerah seyogya diarahkan pada pengelolaan sumber daya alam guna meningkatkan kesejahteraan rakyat. Upaya untuk lebih mendekatkan pelayanan publik kepada masyarakat terlihat dari sasaran otonomi daerah sebagaimana tercantum dalam Undang-Undang No 32 Tahun 2004 Tentang Pemerintah Daerah. Kebijakan desentralisasi dan otonomi daerah pada akhirnya menunjukkan kemampuan pemerintah daerah dalam mengelola daerahnya. Keraf (2006;198-200) menyebutkan lima tujuan desentralisasi, yang meliputi : pertama, desentralisasi dimaksudkan untuk lebih memperlancar dan memaksimalkan pelayanan publik demi menjamin kepentingan masyarakat secara lebih baik. Hal ini bisa dicapai karena pengambilan kebijakan lebih didekatkan pada rakyat, yaitu di daerah. Kedua, demi menjamin demokrasi. Terutama dimaksudkan disini adalah untuk memungkinkan partisipasi publik dalam setiap jenjang pengambilan keputusan dan kebijakan 
politik, dan mungkinkan kontrol serta pertanggung jawaban publik yang lebih baik.

Ketiga, kebijakan publikpun bisa lebih baik karena benar-benar bisa mengakomodasi aspisrasi dan kepentingan rakyat setempat. Ini terutama terjadi, karena pemerintah yang mengambil keputusan tidak saja lebih mudah berkonsultasi dan berkomunikasi dengan masyarakat, melainkan juga mereka mengetahui secara langsung keadaan nyata di daerah tersebut. Keempat, otonomi daerah bertujuan untuk membuka peluang bagi jaminan kesejahteraan dan keadilan ekonomi bagi seluruh rakyat. Dengan desentralisasi, peluang dan akses ekonomi dibuka bagi semua dan dimungkinkan disetiap daerah dan kelompok sosial untuk berperan aktif dalam mengembangkan ekonominya. Serta kelima, desentralisasi membawa dampak positif berupa pemangkasan rentang birokrasi dan berarti mengurangi peluang untuk korupsi. Ini terjadi, tidak saja karena pelayanan publik semakin dekat dengan rakyat, tetapi juga karena kontrol yang meningkat dari rakyat terhadap kekuasaan birokrasi di daerah.

Desentralisasi dan otonomi daerah sebagai kebijakan pemerintah menjadi penting ketika dikaitkan dengan pengelolaan sumber daya alam. Pengelolaan sumber daya alam sebagai unsur lingkungan dengan berbagai keterbatasannya dalam hal regenerasi dan asimilasi memerlukan perhatian yang lebih dari level pemerintahan yang ada. Pembangunan berkelanjutan sebagai cita-cita penyelenggaraan pemerintahan perlu untuk memperhatikan daya dukung lingkungan melalui pengelolaan sumber daya alam yang berkelanjutan. Peran pemerintah propinsi sebagai pihak yang mengkoordinasikan penyelenggaraan pemerintahan antar kabupaten/kota diwilayahnya menjadi sangat strategis. Posisi sumber daya alam yang tidak dapat dipisahkan oleh batas-batas administratif menjadi tantangan yang perlu untuk dipertimbangkan dalam mengelola sumber daya alam. Pembahasan mengenai pengelolaan sumber daya alam tidak bisa lepas dari pembahasan mengenai kewenangan pengelolaan, sebagaimana diatur dalam UndangUndang Nomor 32 Tahun 2004 Tentang Pemerintahan Daerah (UUPD). Dalam UUPD Pasal 17 disebutkan bahwa pemerintahan daerah dalam menyelenggarakan urusan pemerintahan memiliki hubungan dengan Pemerintah dan dengan pemerintahan daerah lainnya, yang salah satunya adalah hubungan dalam pemanfaatan sumber daya alam dan sumber daya lainnya. Hubungan tersebut menimbulkan hubungan administrasi dan kewilayahan antar susunan pemerintahan.

Lebih lanjut disebutkan bahwa hubungan dalam bidang pemanfaatan sumber daya alam dan sumber daya lainnya antara Pemerintah dan pemerintahan daerah meliputi: a. Kewenangan, tanggung jawab, pemanfaatan, pemeliharaan, pengendalian dampak, budidaya, dan pelestarian; b. Bagi hasil atas pemanfaatan sumber daya alam dan sumber daya lainnya; dan c. Penyerasian lingkungan dan tata ruang serta rehabilitasi lahan. Sementara itu hubungan dalam bidang pemanfaatan sumber daya alam dan sumber daya 
lainnya antar pemerintahan daerah meliputi: a. Pelaksanaan pemanfaatan sumber daya alam dan sumber daya lainnya yang menjadi kewenangan daerah; b. Kerja sama dan bagi hasil atas pemanfaatan sumber daya alam dan sumber daya lainnya antarpemerintahan daerah; dan c. Pengelolaan perizinan bersama dalam pemanfaatan sumber daya alam dan sumber daya lainnya.

Khusus dalam kaitan dengan otonomi daerah, harapan untuk mengembangkan dan mengelola potensi sumber daya alam yang ada oleh pemerintah daerah menjadi begitu besar. Apakah realitas membenarkan hal itu atau tidak, itu sangat bergantung pada banyak faktor lainnya. Keraf (2006) menyatakan bahwa secara konseptual otonomi daerah akan lebih menguntungkan bagi pengelolaan sumber daya alam dan lingkungan hidup. Hal ini dapat dilihat dari empat variabel dalam penyelenggaraan otonomi daerah. Pertama, dengan mendekatkan pengambilan kebijakan dan keputusan publikdekat dengan rakyat di daerah, kebijakan dan keputusan publik tersebut diandaikan akan lebih sesuai dengan kenyataan di lapangan mengenai kondisi lingkungan hidupnya. Asumsinya, sulit dipahami bahwa kebijakan dan keputusan publik itu bertentangan dengan kenyataan mengenai kondisi sumber daya alam di daerah. Kedua, ada kontrol lebih langsung dan lebih cepat, bahkan lebih murah, dari masyarakat dan berbagai kelompok kepentingan di daerah. Kontrol yang memungkinkan pemerintah daerah menggunakan kewenangannya demi kepentingan masyarakat. Dengan demikian diasumsikan bahwa kebijakan dan keputusan dibidang pengelolaan sumber daya alam akan lebih mengakomodasi kenyataan di lapangan. Ketiga, dengan otonomi daerah, kepentingan masyarakat lokal yang terkait dengan pengelolaan sumber daya alam dan lingkungan hidup, khususnya masyarakat adat akan lebih bisa diperhatikan dan diakomodasi. Asumsinya, para pengambil keputusan dan kebijakan publik adalah orang-orang yang mengenal masyarakatnya sehingga kepentingan mereka lebih bisa diperhatikan dan diakomodasi. Keempat, nasib setiap daerah ditentukan oleh daerah itu sendiri. Maka masa depan daerah itu juga menjadi tanggung jawab pemerintah dan masyarakat setempat. Dalam kaitan dengan itu, pengelolaan sumber daya alam dan lingkungan hidup harus menjadi salah satu faktor penting yang harus dipertimbangkan secara serius dalam setiap perencanaan pembangunan di daerah tersebut. Ada asumsi cukup kuat bahwa pemerintah daerah dan masyarakat setempat- tidak seperti pemerintah pusat sebelumnya, akan sangat serius mengantisipasi setiap kemungkinan yang terkait dengan sumber daya alam dan lingkungan hidup.

Lay (2007) menyatakan bahwa lingkungan memiliki karakteristik khas yang idealnya dapat dijadikan titik rujuk bagi politik sebagai instrumen pengaturan kepentingan bersama. Tiga karakteristik lingkungan tersebut dapat diidentifikasi sebagai berikut : pertama, watak lingkungan sebagai sebuah kesatuan sistem melintasi sekat-sekat administrasi pemerintahan dan politik. Kedua, lingkungan melekat didalamnya kepentingan paling 
subyektif dari manusia sebagai mahluk, terlepas dari ruang politik dan bebas dari perjalanan waktu. Ketiga, Daya menghukum lingkungan yang timbul sebagai akibat dari pengabaian manusia manusia atas lingkungan punya sifat yang sangat khas, yakni indiskriminatif.

Ada hubungan erat antara penyelenggaraan pemerintahan yang baik dengan pengelolaan lingkungan yang baik. Bahkan ada korelasi sangat positif antara penyelenggaraan pemerintahan yang baik dengan pengelolaan lingkungan yang baik. Penyelenggaraan pemerintahan yang baik akan mempengaruhi dan menentukan pengelolaan lingkungan hidup yang mencerminkan tingkat penyelenggaraan pemerintahan yang baik. Tan papen ye leng gar a a n pemerintahan yang baik, sulit mengharapkan akan adanya pengelolaan lingkungan jidup yang baik. Penyelenggaraan pemerintahan yang baik akan menentukan komitmen penyelenggara pemerintahan terhadap lingkungan hidup. (Keraf, 2006 : 201).

\section{METODE PENELITIAN}

Jenis penelitian ini adalah bersifat deskriptif yaitu suatu penelitian yang menggambarkan pengelolaan sumber daya alam dalam era otonomi daerah dengan memfokuskan diri pada kewenangan pemerintahan pada level propinsi di Propinsi Kalimantan Timur. Sementara itu, lokasi penelitian dilaksanakan di Propinsi Kalimantan Timur dengan memilih lembaga/dinas sebagai tempat yaitu ; Dinas Kehutanan, Dinas Pertambangan dan Dinas Perkebunan yang merupakan lembaga dengan peran sentral dalam pengelolaan sumber daya alam, khususnya yang terkait dengan kewenangan

pengelolaannya pada level propinsi.

Dalam pelaksanaan penelitian, informan ditentukan dengan teknik purposive dengan mempertimbangkan kemampuan individu yang askan menjadi key informan maupun informan dalam penelitian ini. Untuk melengkapi data yang telah diperoleh maka dipilih informan yang akan memberikan informasi lebih mendalam mengenai topik penelitian. Informan bersumber dari pemerintah propinsi (dinas kehutanan, dinas pertambangan dan dinas perkebunan). Lembaga Swadaya Masyarakat dari Jaringan Advokasi Tambang (Jatam) \& Walhi, anggota DPRD Propinsi Kalimantan Timur, Akademisi (dosen Fakultas Kehutanan, Fisipol dan Lingkungan), dan masyarakat yang memiliki pengalaman dan pengetahuan tentang pengelolaan sumber daya alam di Propinsi Kalimantan Timur. Pengumpulan data dilaksanakan melalui wawancara mendalam dan focus group discussion.

Secara umum prosedur yang dilakukan dalam penelitian ini terdiri dari dua tahap yaitu studi pustaka dan penelitian lapangan. Studi pustaka dilakukan untuk mendapatkan data berupa hasil-hasil penelitian ataupun buku-buku yang relevan dengan materi penelitian ini. Hasil-hasil penelitian dan buku-buku dengan konsep dan teori yang relevan dengan materi penenlitian ini akan sangat bermanfaat bagi langkah selanjutnya dalam penelitian ini, baik pada tahap awal maupun pada tahap akhir khususnya ketika melaksanakan analisis data. Penelitian lapangan dilakukan dengan tujuan untuk memperoleh data empiris 
tentang aspek-aspek yang dikaji dalam penelitian ini. Penelitian ini dilapangan dilakukan dengan melaksanakan observasi, wawancara mendalam, maupun FGD. Sementara itu dalam hal pengumpulan data, penelitian ini membutuhkan dua jenis data yaitu data primer dan data sekunder. Data primer adalah data yang diperoleh langsung dari informan. Data sekunder adalah data yang diperoleh melalui laporan atau dokumen-dokumen.Data-data yang diperoleh selajutnya akan dianalisis dengan pendekatan kualitatif. Model analisis yang digunakan mengacu pada 3 (tiga) langkah utama, yaitu : Reduksi Data, pengorganisasian data, dan inerpretasi data. Tiga tahapan analisis tersebut diharapkan mampu mengungkap secara mendalam mengenai pengelolaan sumber daya alam di Propinsi Kalimantan Timur.

\section{KONDISI SUMBER DAYA ALAM DI PROPINSI KALIMANTAN TIMUR}

Propinsi Kalimantan Timur merupakan propinsi dengan kekayaan sumber daya alam (SDA) yang begitu melimpah. Hal ini tidak saja pada potensi SDA yang tidak terbarukan, akan tetapi lebih dari itu dimana semua sumber daya yang ada tersedia. Potensi sumber daya alam Kalimantan Timur meliputi : Sub Sektor Kehutanan, Pertanian, Perkebunan, Pesisir dan Kelautan, Pertambangan Berupa Gas, minyak bumi, dan mineral, bahan galian logam dan industri bangunan ( emas, nikel, antimonit, besi, timah hitam dan seng, rutil, batu gamping, kaolin, kristal kuarsa, pasir kuarsa, fospat, lempung, andesit, gipsum, intan, marmer, serpentinit, peridotit, bentonit, diorit).

Pengelolaan sektor kehutanan merupakan sub sektor yang begitu favorit dalam kurung waktu 32 tahun pada masa orde baru, letak geografis Propinsi Kalimantan Timur menjadikan lokasi ini menjadi salah satu tujuan dari pengelola sektor kehutanan. Luas hutan di Kalimantan Timur dari tahun-ketahun terus mengalami penyusutan baik oleh pengelolaan yang memiliki $\quad \mathrm{HPH}$ maupun oleh pembalakan liar. Data Tahun 2007 menunjukkan bahwa luas hutan yang tersisa sekita 21.146.648,26 Ha yang terbagi menjadi 6 (enam) jenis hutan yang meliputi ; hutan lindung, hutan suaka alam dan wisata, hutan produksi terbatas, hutan produksi tetap, hutan produksi yang dapat dikonversi dan hutan pendidikan / penelitian. Dari 6 (enam) jenis hutan tersebut, yang terluas adalah hutan produksi terbatas dan hutan produksi yang dapat di konversi. Untuk lebih jelasnya mengenai potensi kehutanan berdasarkan tata guna hutan di Propinsi Kalimantan Timur dapat Kita Lihat pada Tabel 1. 
OTONOMI DAERAH DAN PENGEL OLAAN SUMBER DAYA ALAM DI PROVINSI KALIMANTANTIMUR (STUDI KASUS KEWENANGAN PENGELOLAAN KEHUTANAN, PERTAMBANGAN DAN PERKEBUNAN)

Jauchar B.

Tabel 1. Luas Hutan Menurut Tata Guna Lahan Kesepakatan di Propinsi Kalimantan Timur Tahun 2009 (ha)

\begin{tabular}{|c|c|c|c|c|c|c|c|c|}
\hline No & $\begin{array}{c}\text { Kabupaten / } \\
\text { Kota }\end{array}$ & $\begin{array}{l}\text { Hutan } \\
\text { Lindung }\end{array}$ & $\begin{array}{c}\text { Hutan Suaka } \\
\text { Alam / Wisata }\end{array}$ & $\begin{array}{c}\text { Hutan } \\
\text { Produksi } \\
\text { Terbatas }\end{array}$ & $\begin{array}{l}\text { Hutan } \\
\text { Produksi } \\
\text { Tetap }\end{array}$ & \begin{tabular}{|c|} 
Hutan Tetap \\
Total (3) + (4) \\
$+(5)$ \\
\end{tabular} & $\begin{array}{c}\text { Hutan Produksi } \\
\text { yang Dapat di } \\
\text { Konversi }\end{array}$ & \begin{tabular}{|c|} 
Hutan \\
Pendidikan \\
/ Pelatihan
\end{tabular} \\
\hline 1 & 2 & 3 & 4 & 5 & 6 & 7 & 8 & 9 \\
\hline 1 & Paser & 116.952 & 109.302 & 145.350 & 257.126 & $511.778,00$ & 531.664 & -- \\
\hline 2 & Kutai Barat & $745.551,41$ & 5.500 & $587.644,98$ & 643.578 & $1.236 .733,98$ & $892.125,22$ & -- \\
\hline 3 & $\begin{array}{l}\text { Kutai } \\
\text { Kartanegara } \\
\end{array}$ & 213.959 & 11.621 & 507.614 & 781.762 & \begin{tabular}{|l|}
$1.300 .997,00$ \\
\end{tabular} & 1.073 .009 & 781.762 \\
\hline 4 & Kutai Timur & 454.708 & 54.710 & 1.090 .893 & 969.952 & $2.115 .555,00$ & 1.043 .716 & -- \\
\hline 5 & Berau & $339.391,1$ & $523.431,1$ & $631.491,45$ & $616.210,93$ & $1.771 .133,48$ & 455.315 & -- \\
\hline 6 & Malinau & 708.647 & 1.360 .500 & 1.624 .356 & 447.910 & $3.342 .166,00$ & 269.813 & -- \\
\hline 7 & Bulungan & 167.748 & -- & 493.583 & 461.769 & $955.352,00$ & 542.199 & -- \\
\hline 8 & Nunukan & 157.855 & -- & 164.844 & 310.387 & $475.231,00$ & 470.914 & -- \\
\hline 9 & $\begin{array}{l}\text { Penajam } \\
\text { Paser Utara }\end{array}$ & $21.495,75$ & -- & -- & $45.282,36$ & $45.282,36$ & $145.282,26$ & -- \\
\hline 10 & Balikpapan & 15.000 & 15.000 & -- & -- & 15.000 & 23.562 & -- \\
\hline 11 & Samarinda & -- & -- & -- & 386 & 386,00 & 62.075 & -- \\
\hline 12 & Tarakan & 3.705 & 7.048 & -- & 6.860 & $7.908,00$ & 13.252 & -- \\
\hline 13 & Bontang & 21.728 & 720 & -- & 1.141 & $1.861,00$ & 5.248 & \\
\hline & Jumlah & $2.966 .740,26$ & $2.081 .832,10$ & $5.245 .776,43$ & $4.524 .346,29$ & $11.869 .972,48$ & $5.528 .174,48$ & 781.762 \\
\hline
\end{tabular}

Upaya pemerintah dalam melestarikan potensi kehutanan dilaksanakan melalui penertiban dan pelarangan eksploitasi sektor kehutanan. Pergeseran paradigma dalam pengelolaan sumber daya alam kemudian ditandai dengan meningkatnya jumlah produksi dari sektor pertambangan. Propinsi Kalimantan Timur sebagai daerah dengan cadangan kekayaan pertambangan gas, mineral, batu bara dan minyak bumi kemudian muncul sebagai salah satu daerah penyuplai sumber-sumber kebutuhan seperti minerba, gas dan minyak bumi tersebut. Berdasarkan data yang ada di dinas pertambangan dan energi Propinsi Kalimantan Timur potensi sumber daya mineral yang ada dapat diklasifikasikan seperti pada tabel 2.

Tabel 2. Proyeksi Potensi Sumber Daya Mineral Propinsi Kalimantan Timur

\begin{tabular}{|c|c|c|}
\hline No & Jenis & Estimasi Kandungan / Lokasi \\
\hline 1 & Batu Bara & 19, 567.79 ( M Ton) dengan Cadangan 2,410.33 (M Ton) \\
\hline 2 & Emas & $\begin{array}{l}\text { 60,50 Juta Ton, Tersebar di Kab. Pasir, Kab. Kutai Barat, } \\
\text { dan Kab. Bulungan }\end{array}$ \\
\hline 3. & $\begin{array}{l}\text { Bahan Galian Industri / } \\
\text { Bangunan }\end{array}$ & $\begin{array}{l}\text { Nikel ; 120.000.000 Ton, Antomonit ; 87.79 Ton, Besi ; } \\
\text { 18.000.000 Ton, Timah Hitam ; Indikatif, Rutil ; } \\
\text { Indikatif, Batu Gamping ; 25.695.523.660 Ton, Kaolin ; } \\
\text { 9.029.832, Kristal Kuarsa ; 6.000.000 Ton, Fospat ; } \\
\text { 1.680 Ton, Lempung ; 2.036.085.075 Ton, Andesit ; } \\
\text { 35.000.000 M , Gipsun ; Indikatif, Intan ; I ndikatif, } \\
\text { Marmer ; 381. 750.000 M, Sarpetinit ; } 240.000 .0^{3} 00 \mathrm{M} \text {, } \\
\text { Peridotit ; 801.450.000 M , Beentonit ; } 27.800 .000^{3} \mathrm{M} \text {, } \\
\text { Diorit ; 37.250.135 M }\end{array}$ \\
\hline
\end{tabular}


OTONOMI DAFRAH DAN PENGEL OLAAN SUMBER DAYA ALAM DI PROVINSI KALIMANTANTIMUR (STUDI KASUS KEWENANGAN PENGELOLAAN KEHUTANAN, PERTAMBANGAN DAN PERKEBUNAN)

Jauchar B.

\begin{tabular}{|c|l|l|}
\hline 4. & Minyak & $\begin{array}{l}\text { Cadangan Minyak ; 920 Milliar Barrel (MMSTB), } \\
\text { dengan Progosa (ribu ba rrel) } ; 49,331.23, \text { Realisasi (ribu } \\
\text { barrel) } ; 52,809.53\end{array}$ \\
\hline 5. & Gas Alam & $\begin{array}{l}\text { Cadangan } ; 47,39 \text { Trilun SCF, dengan Progosa (ribu } \\
\text { MMTBU) } ; 968,711.80, \text { Realisasi } ; 1.072 .815 .90 \text { (ribu } \\
\text { MMBTU) }\end{array}$ \\
\hline
\end{tabular}

Sumber: Profil Potensi Energi dan Sumber Daya Mineral Propinsi Kalimantan Timur 2010

Seiring dengan semakin

peningkatan jumlah penduduk dan tuntutan akan diversifikasi pengelolaan sumber daya alam yang tidak hanya bertumpu pada sektor yang tidak terbarukan, maka mulai tahun 2002 pemerintah daerah terus memacu untuk mengembangkan sub sektor perkebunan dengan berbagai varietasnya. Tanaman perkebunan yang dikembangkan di Propinsi Kalimantan Timur antara lain : karet, kopi, kelapa, cengkeh, coklat, kelapa sawit, dan lainnya. Pembudidayaan tanaman perkebunan termasuk didalamnya perkebunan besar pemerintah, perkebunan besar swasta, dan perkebunan rakyat. Luas Areal perkebunan terus meningkat dari tahun-ketahun sebagai bentuk dukungan kepada pemerintah untuk memanfaatkan lahan tidur yang selama tidak dimaksimalkan. Untuk lebih jelasnya mengenai luas tanaman perkebunan di Propinsi Kalimantan Timur Dapat dilihat pada Tabel 3.

Tabel 3. Luas Tanaman Perkebunan Menurut Jenis Tanaman di Kalimantan Timur (ha)

\begin{tabular}{|c|c|c|c|c|c|c|c|c|}
\hline Tahun & Karet & Kelapa & Kopi & Lada & Cengkeh & Kakao & $\begin{array}{c}\text { Kelapa } \\
\text { Sawit }\end{array}$ & Lain-Lain \\
\hline 2003 & $60.477,50$ & $49.466,00$ & $16.512,50$ & $13.662,00$ & 291,00 & $32.927,50$ & $159.076,00$ & $6.631,50$ \\
\hline 2004 & $60.154,50$ & $46.307,50$ & $16.104,50$ & $13.756,00$ & 272,00 & $36.071,00$ & $171.580,50$ & $6.882,00$ \\
\hline 2005 & $62.426,00$ & $45.643,00$ & $17.787,50$ & $13.821,00$ & 228,50 & $37.296,00$ & $201.087,00$ & $7.385,00$ \\
\hline 2006 & $64.957,00$ & $47.734,00$ & $17.409,00$ & $14.768,00$ & 253,00 & $41.307,00$ & $225.352,00$ & $8.741,50$ \\
\hline 2007 & $67.891,00$ & $34.537,00$ & $15.067,00$ & $14.508,00$ & 210,50 & $34.557,50$ & $339.292,50$ & $7.620,50$ \\
\hline
\end{tabular}

Pengelolaan tiga sub sektor sumber daya alam tersebut oleh pemerintah daerah baik pada level pemerintah propinsi maupun kabupaten/kota memerlukan dukungan berupa perangkat peraturan perundangundangan yang menjadi dasar bagi kewenangan yang dimiliki oleh masing-masing level pemerintahan. Implementasi Undang-Undang No 32 Tahun 2004 diakui atau tidak telah memberikan pengaruh yang begitu besar pada level propinsi. Hal ini terkait dengan besarnya kewenangan yang dimiliki dalam pengelolaan potensi sumber daya alam yang ada dalam wilayah administratifnya. Berbagai kewenangan yang selama ini melekat pada pemerintah propinsi beralih ke kabupaten/kota, sementara urusanurusan yang terkait dengan penyelesaian sengketa pengelolaan akan tetap ditinggalkan untuk pemerintah propinsi. Kenyataan tersebut kemudian menjadi suatu hal yang perlu untuk disikapi guna menetapkan kembali posisi pemerintah propinsi dalam posisi tawar yang strategis dalam rangka pembangunan wilayah secara menyeluruh. 
Kewenangan Pengelolaan Sumber Daya Alam Pada Level Pemerintah Propinsi di Propinsi Kalimantan Timur

\section{Pengelolaan Hutan}

Kalimantan Timur dikenal sebagai salah satu propinsi dengan kawasan hutan yang luas. Berdasarkan data tahun 2006, luas kawasan hutan yang ada sekitar 21.146.648 ha, terdiri atas hutan lindung, hutan suaka alam dan wisata, hutan produksi terbatas, hutan produksi tetap, hutan produksi yang dapat dikonversi, dan hutan pendidikan/penelitian. Hutan produksi terbatas dan hutan produksi yang dapat dikonversi merupakan jenis hutan yang terluas, yakni 5.245.776 ha dan 5.528.174 ha. Dengan kawasan hutan yang luas ini, sejatinya pemerintah propinsi memiliki tanggung jawab dalam mengelola hutan yang sebesarbesarnya untuk kepentingan masyarakat, khususnya masyarakat Kalimantan Timur.

Dalam rangka melaksanakan amanah tersebut, sudah barang tentu diperlukan sebuah kewenangan yang jelas agar pengelolaan dapat berjalan sebagaimana mestinya. Kewenangan yang dimaksud adalah pelimpahan sebagian wewenang pemerintah pusat kepada pemerintah propinsi untuk melakukan pengelolaan hutan.

Pemberian kewenangan ini seharusnya dengan peraturan perundang-undangan yang kemudian menjadi payung hukum dalam mengatur batas kewenangan antara pusat dan daerah, sehingga tidak terjadi tumpang tindih kewenangan yang dapat berakibat pada inefisiensi pengelolaan. Payung hukum pelaksanaan kewenangan ini mutlak diperlukan oleh pemerintah daerah (propinsi) sebagai landasan dalam mengelola dan memanfaatkan hutan yang ada di wilayahnya, mulai dari perencanaan hingga perlindungan hutan dan konservasi alam.

Meski telah ada UndangUndang tentang penataan ruang yang mengatur tentang pembagian kewenangan dan tanggung jawab antara pemerintah pusat, pemerintah propinsi, dan pemerintah kabupaten/kota dalam melakukan pengelolaan kawasan hutan yakni UU No. 26 Tahun 2007, namun pada kenyataannya belum menjadi solusi terbaik atas persoalan yang sering muncul ke permukaan terkait dengan pengelolaan hutan ini. Masih seringnya terjadi tumpang tindih (overlap) penggunaan lahan untuk keperluan yang berbeda, misalnya adanya lahan yang memiliki izin penggunaan ganda (untuk keperluan industri kehutanan, pertambangan, dan perkebunan) dan saling klaim antara pusat dan daerah merupakan sebuah indikator belum terlaksananya UU ini. Fenomena ini menunjukkan bahwa belum ada sinergi positif antara pusat dan daerah terkait dengan kewenangan pengelolaan hutan.

Berikut ini akan digambarkan kewenangan pengelolaan hutan di Kalimantan Timur.

\section{a. Kewenangan Pengelolaan Sektor Kehutanan Pada Level Propinsi Dalam kasus Kalimantan} Timur, berdasarkan data yang diperoleh dari pelaksanaan Focus Group Discussion $(F G D)$ tentang Otonomi Daerah dan Pengelolaan Sumberdaya Alam Kalimantan Timur yang diselenggarakan pada tanggal 28 Juli 2009 di Universitas Mulawarman Samarinda, terungkap bahwa belum 
ada aturan (PP) yang mengatur tentang penyerahan sebagian kewenangan penyelenggaraan kehutanan oleh pusat kepada pemerintah daerah (Propinsi Kalimantan Timur) sebagai amanat dari pasal 66 UU Kehutanan No. 41/1999. Kewenangan yang ada hanya sebatas kewenangan administrasi yang dilaksanakan oleh Dinas Kehutanan Propinsi. Propinsi lebih banyak bertindak sebagai pemberi rekomendasi ketimbang pemberi ijin dalam setiap kegiatan pengelolaan hutan. Akibatnya, propinsi menjadi pihak yang "tidak berdaya" atas hutan yang ada di wilayahnya. Darmadi menyebutkan bahwa terkait dengan pengelolaan sektor kehutanan perlu revisi terhadap UU No. 32 Tahun 2004 khususnya terkait dengan kewenangan pemerintah propinsi. Hal tersebut didasarkan dari data yang menyebutkan bahwa dari 14,67 Juta Ha bhutan yang ada $\pm 90 \%$ telah rusak akibat pengelolaan hutan yang tidak bertanggung jawab. Maka terkait dengan hal tersebut diperlukan adanya penyamaan persepsi dalam mengelola sektor kehutanan. 2 Kewenangan pengelolaan sektor hutan yang belum menempatkan posisi propinsi sebagai sentral dari pengelolaan sektor kehuatanan juga disebutkan oleh wakil dari BLH yang menyatakan bahwa dalam penyusunan renstra kehutanan kedepan perlu untuk penekanan pada sifat regionalismenya sehingga berbagai persoalan dapat diselesaikan dengan penekanan pada fungsi dan kewenangan dari masing-masing level pemerintahan.
Salah satu contoh ketiadaan kewenangan propinsi bila ditinjau dari kawasan budidaya hutan yang telah ditetapkan oleh menteri kehutanan tentang Kawasan Budidaya Non Kehutanan (KBNK) dalam penempatan posisi pertambangan dan perkebunan. Kewenangan diserahkan kepada kabupaten (bupati) dan kota (walikota), sedangkan posisi propinsi dalam hal ini tidak muncul. Besarnya kewenangan kabupaten/kota ini berimplikasi pada lemahnya kekuatan propinsi. Kewenangan propinsi hanya sebatas administratif (rekomendasi) dan penyelesaian konflik yang terjadi berkaitan dengan pengelolaan hutan, misalnya konflik antar daerah kabupaten/kota dan konflik antara daerah dengan masyarakat lokal. Jika terkait dengan penggunaan anggaran pengelolaan, pusat dan kabupaten/kota memiliki kewenangan yang besar. Kewenangan ini merupakan konsekuensi logis dari penerapan otonomi daerah yang menitikberatkan titik berat otonomi daerah pada daerah kabupaten/kota sebagaimana diatur dalam Undang-Undang No. 32 tahun 2004 tentang Pemerintah Daerah.

\section{b. Kendala Yang Dihadapi Dalam Pengelolaan Sektor Kehutanan Pada Level Propinsi}

Salah satu kendala yang mengemuka dalam penelitian terkait dengan kewenangan pengelolaan hutan pada level propinsi karena dimasukkannya pengelolaan hutan pada urusan pilihan seperti yang tercantum dalam UU No. 32/2004 pasal 13 yang menyebutkan bahwa urusan

${ }^{2}$ Damai darmadi dalam sesi yang membahas sektor kehutanan pada FGD di Rektorat Unmul 28 Juli 2009. ${ }^{3}$ BLH Kaltim dalam FGD 28 Juli 2009. 
pemerintahan propinsi yang bersifat pilihan meliputi urusan pemerintahan yang secara nyata ada dan berpotensi untuk meningkatkan kesejahteraan masyarakat sesuai dengan kondisi, kekhasan, dan potensi unggulan daerah yang bersangkutan. Untuk Kalimantan Timur, kekhasan dan potensi unggulan daerah yang dimiliki salah satunya adalah hutan. Selanjutnya diperkuat dengan PP No. 38/2007 tentang Pembagian Urusan Pemerintahan antara Pemerintah, Pemerintah Propinsi, dan Pemerintah Kabupaten/Kota pasal 6 ayat (4) yang menyebutkan bahwa urusan pilihan yang dimaksud salah satunya adalah kehutanan.

Pengelolaan hutan Kalimantan Timur yang masuk urusan pilihan ini kemudian mengakibatkan tidak maksimalnya sinergi antara pusat dan daerah dalam pengelolaan hutan. Minimya kewenangan yang diserahkan kepada propinsi menjadi kendala tersendiri karena kreatifitas yang seharusnya muncul dari wilayah di mana hutan itu dikelola menjadi tidak ada.

Kendala lain adalah belum ditetapkannya Rencana Tata Ruang W i l a y a P r op in s i ( RT R W P) Kalimantan Timur dalam bentuk Peraturan Daerah (perda), padahal perda ini sangat dibutuhkan sebagai panduan dalam menetapkan zona-zona kawasan pengelolaan hutan. Hal tersebut dibenarkan oleh perwakilan dari Jaringan Advokasi Tambang (Jatam) yang menyatakan bahwa dengan tidak disahkannya RTRWP maka pengelolaan sektor kehutanan didaerah tidak jelas, tidak ada road map dalam pengelolaan hutan di daerah. Hal tersebut berimplikasi pada pengelolaan hutan tidak berkelanjutan dan cenderung eksploratif. 4 Tidak adanya road maaf yang jelas mengenai pengelolaan hutan juga berimbas pada semakin sulitnya akses masyarakat dalam berpartisipasi untuk menjaga dan mengelola hutan agar tetap sesuai dengan yang diharapkan.

\section{c. Upaya Pemerintah Propinsi dalam Memperbaiki Pengelolaan Hutan}

Untuk mengatasi persoalan kurangnya kewenangan propinsi dalam pengelolaan hutan adalah dengan melakukan perubahan penekanan dari urusan pilihan menjadi urusan wajib. Dengan perubahan ini diharapkan propinsi menjadi lebih berdaya dan memiliki peran penting. Propinsi perlu mengembangkan konsep yang jelas tentang perencanaan, pengelolaan, dan perlindungan hutan melalui suatu kajian pengelolaan kawasan hutan agar dapat menjadi acuan bagi pusat dan daerah dalam melakukan sinergi pengelolaan hutan. Bukan hanya kabupaten/kota, propinsi pun harus diberi ruang untuk mengembangkan kreatifitas dan kreasi dalam mengelola hutan.

Propinsi harus menyiapkan diri untuk mengantisipasi kemungkinan terjadinya konflik kepentingan yang biasanya muncul mengiringi pengelolaan sumberdaya hutan. Propinsi perlu menjadi jembatan atas kepentingan pusat dan kabupaten/kota dengan menyiapkan perangkat

pe merint a h a n $\mathrm{g}$ u n a mengoptimalisasikan berbagai

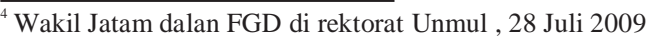


kegiatan pengelolaan sumber kehutanan.

\section{Pengelolaan Pertambangan}

Sektor pertambangan sebagai

salah satu sektor unggulan dalam pengelolaan sumber daya alam di Propinsi Kalimantan Timur perlu untuk mendapatkan perhatian serius. Hal ini terkait dengan dampak yang

diakibatkan dari kegiatan pertambangan tersebut. Kegiatan pertambangan di Kalimantan Timur mencakup pertambanngan migas dan non-migas. Dari jenis kegiatan itu, minyak bumi dan gas alam merupakan hasil tambang yang sangat besar pengaruhnya terhadap kehidupan perekonomian Kalimantan Timur dan Indonesia pada umumnya. Hal ini didasari oleh fakta bahwa salah satu sumber pemasok devisa negara adalah bersumber dari pertambangan. Selain memperhitungkan jumlah pemasukan negara dari sektor pertambangan juga perlu untuk kemudian melihat dampak yang ditimbulkan dari kegiatan pertambangan terhadap lingkungan dan ekosistem yang ada disekitarnya. Operasionalisasi pertambangan dengan berbagai jenisnya pada suatu lingkungan pada akhirnya akan membawa dampak pada ketidakseimbangan lingkungan sebagai imbas pengelolaan lingkungan itu sendiri. Dalam kondisi tersebut peran pemerintah sebagai kontrol untuk menjaga kesinambungan sumber daya alam di daerahnya perlu untuk dihadirkan demi keberlanjutan pembangunan itu sendiri. Tidak dapat dipungkiri bahwa sektor pertambangan khususnya ; mineral, gas, minyak dan batubara merupakan energi yang tidak terbarukan. Sehingga mekanisme pengelolaan sumber daya tersebut perlu untuk secara ketat diberlakukan sehingga dapat dinikmati oleh generasi penerus. Kewenangan yang dimiliki oleh masing level pemerintahan menjadi kunci utama dalam mengefektifkan berbagai aktifitas. Hal ini tidak terkecuali pada pemerintahan level propinsi untuk dapat mengelola dan mensinergikan berbagai persoalan pertambangan yang ada di Propinsi Kalimantan Timur.

\section{a. K e w e n a n a n P e n g l o l a a n Pertambangan di Level Propinsi} Ditetapkannya UndangUndang No 32 Tahun 2004 tentang pemerintahan daerah membawa pengaruh pada penyelenggaraan pemerintahan bidang pertambangan, Hal ini terutama pada pergeseran urusan bidang pertambangan yang semula hanya pada galian golongan $\mathrm{C}$, kemudian mengarah pada semua kewenangan pertambangan yang ada di daerah untuk diselesaikan sesuai dengan kebutuhan dan kemampuan yang ada di daerah. Implementasi pasal-pasal UU No. 32 Tahun 2004 tentang kewenangan pengelolaan sektor pertambangan di daerah membawa ketimpangan pada level propinsi. Besarnya kewenangan yang dimiliki oleh pemerintah kabupaten/kota dalam menerbitkan dan mengelola berbagai permasalahan pertambangan ternyata tidak sejalan dengan kewenangan yang dimiliki oleh pemerintah propinsi. Hal ini berpengaruh pada posisi tawar dari pemerintah propinsi terhadap pengelolaan sektor pertambangan tersebut.

Kewenangan pengelolaan sektor pertambangan sebagaimana 
diatur dalam Peraturan Pemerintah Republik Indonesia Nomor 38 Tahun 2007 tentang pembagian urusan pemerintahan antara pemerintah, pemerintahan daerah propinsi, dan pemerintah daerah kabupaten/kota dalam bidang energi dan sumber daya mineral (mineral, batu bara, panas bumi, dan air) meliputi ; a. Pembuatan peraturan perundang-undangan daerah propinsi bidang mineral, batu bara, panas bumi dan air tanah. $b$.

Penyusunan data dan informasi usaha pertambangan mineral dan batu bara serta panas bumi lintas kabupaten kota. c. Pemberian izin usaha pertambangan mineral, batu bara dan panas bumi pada wilayah lintas kabupaten/kota dan paling jauh 12 (dua belas) mil laut diukur dari garis pantai kearah laut lepas dan/atau kearah perairan kepulauan. d. Pemberian izin usaha pertambangan mineral, dan batu bara untuk operasi produksi yang berdampak lingkungan langsung lintas kabupaten kota dengan paling jauh 12 (dua belas) mil laut diukur dari garis pantai ke arah laut lepas dan / atau ke arah perairan kepulauan. e. Pembinaan dan pengawasan pelaksanaan izin usaha pertambangan mineral, batu bara dan panas bumi pada wilayah lintas kabupaten/kota dan paling jauh 12 (dua belas) mil laut diukur dari garis pantai ke arah laut lepas dan/atau ke arah perairan kepulauan. f. Pemberian izin badan usaha jasa pertambangan mineral, batubara, dan panas bumi dalam rangka PMA dan PDMN lintas kabupaten/kota. g. Pengelolaan, pembinaan dan pengawasan pelaksanaan izin usaha jasa pertambangan mineral, batubara, dan panas bumi dalam rangka penanaman modal lintas kabupaten/kota.
h.Pembinaan dan pengawasan keselamatan dan kesehatan kerja, lingkungan pertambangan termasuk reklamasi lahan pasca tambang, konservasi dan peningkatan nilai tambah terhadap usaha pertambangan mineral, batu bara dan panas bumi, pada wilayah lintas kebupaten/kota atau yang berdampak regional. i. Pembinaan dan pengawasan penguasahaan KP lintas kabupaten/kota, j. Pembinaan dan pengawasan keselamatan dan kesehatan kerja, lingkungan pertambangan termasuk reklamasi lahan pasca tambang, konsevasi dan peningkatan nilai tambah terhadap KP lintas kabupaten/kota. k. Pembinaan dan pengawasan pelaksanaan izin usaha pertambangan mineral, dan batubara untuk operasi produksi, serta panas bumi yang berdampak lingkungan langsung lintas kabupaten/kota, 1. Pengelolaan data dan informasi mineral, batu bara, panas bumi dan air tanah serta pengusahaan dan SIG wilayah kerja pertambangan di wilayah propinsi. $\mathrm{m}$. Penetapan potensi panas bumi dan air tanah serta neraca sumber daya dan cadangan mineral dan batubara di wilayah propinsi. serta $n$. Pengangkatan dan pembinaan inspektur tambang serta pembinaan jabatan fungsional propinsi.

Guna mendukung pelaksanaan tugas dan fungsi instansi terkait dalam pengelolaan pertambangan, maka dikeluarkan SK. Gubernur Kaltim No. 26 Tahun 2004 tentang lingkungan pertambangan. Beberapa parameter yang digunakan dalam menilai kondis pertambangan dalam SK tersebut ternyata belum cukup untuk mendorong instansi pertambangan di level propinsi untuk mengkoordinir 
pertambangan secara menyeluruh. Hasil wawancara kepala bidang pertambangan umum dinas pertambangan propinsi Kaltim menyebutkan bahwa ; Dinas pertambangan pada level pripinsi merupakan lembaga dengan wilayah kerja yang luas dengan kewenangan yang sangat sedikit. Fungsi yang jalankan oleh distambeng propinsi hanya pada wilayah koodinasi. (hasil wawancara, juli 2009). Keterbatasan dalam sektor kewenangan mengakibatkan dinas pertambangan dan energi pada level propinsi pada akhirnya hanya akan menjadi lembaga koordinasi dengan kewenangan yang terbatas.

Jenis kewenangan yang dimiliki pemerintahan pada level propinsi menempatkan posisi tawar propinsi dalam pengelolaan sektor pertambangan begitu lemah, sementara tuntutan globalisasi mengarahkan pada peningkatan peran propinsi yang tidak hanya pada bidang adminsitatif tetapi pada semua lini yang terkait dengan penyelenggaraan dan pengelolaan sektor pertambangan.

\section{b. Kendala-Kendala Yang dihadapi dalam Pengelolaan Pertambangan Pada level Propinsi}

Upaya pemerintah propinsi dalam meningkatkan perannya untuk pengelolaan sektor pertambangan terkendala pada jenis kewenangan tersebut. Kewenangan pengelolaan dalam UU No. 32 Tahun 2004 yang menempatkan pengelolaan sektor pertambangan sebagai urusan pilihan pada dasarnya telah menunjukkan posisi kewenangan tersebut. Sementara tuntutan perubahan zaman dan lingkungan masyarakat Kalimantan Timur dalam hal pengelolaan sektor pertambangan akan lebih maksimal dengan jika urusan pengelolaan sektor pertambangan diarahkan pada pilihan wajib yang memungkinkan pemerintah propinsi memiliki nilai tawar lebih dibandingkan pemerintah kabupaten/kota.

Kewenangan pemerintah kabupaten/kota dalam menerbitkan izin pengelolaan pertambangan tanpa koordinasi dengan pemerintah propinsi pada akhirnya akan mengakibatkan munculnya kesimpangsiuran informasi dalam pengelolaan pertambangan di Propinsi Kalimantan Timur. Dinas Pertambangan dan energi hanya menerima laporan yang terkait dengan sengketa yang muncul dalam pengelolaan pertambangan tersebut, sementara urusan-urusan yang memungkinkan pencegahan permasalahan, khususnya lintas kabupaten/kota tidak melibatkan pemerintah propinsi. Kondisi ini berdampak pada hilangnya koordinasi antara dinas dari level kabupaten/kota ke pemerintah propinsi sebagai wujud dari ketiadaan wewenang pemerintah propinsi untuk mengatur dan mengelola bidang pertambangan di kabupaten /kota. Hal tersebut senada dengan pernyataan perwakilan koalisi masyarakat untuk pertambangan dan perwakilan dinas kehutanan yang menyatakan ; pengelolaan sektor pertambangan harus sinergi dimana kewenangan besar masalah pertambangan seharusnya berada di level propinsi. Hal tersebut dimaksudkan agar pengelolaan kawasan dapat berjalan secara 
berkesinambungan dengan memperhatikan daya dukung lingkungan sekitarnya.s

$$
\text { Pengelolaan sektor }
$$

pertambangan oleh pemerintah

Propinsi Kalimantan Timur yang tidak sejalan dengan kebijakan pemerintah kabupaten/kota. Besarnya kewenangan yang dimiliki oleh pemerintah kabupaten/kota mengakibatkan penerbitan izin dalam pengelolaan pertambangan sesuai dengan keinginan pemerintah kabupaten/kota tanpa memperhatikan rencana tata ruang dan wilayah akan berdampak pada lingkungan. Pembangunan lingkungan khususnya sektor pertambangan merupakan suatu kesatuan yang tidak dapat dipisahkan oleh batas-batas administratif termasuk oleh batas-batas wilayah kabupaten/kota.

\section{c. Upaya Pemerintah Propinsi Dalam Mengoptimalkan Pengelolaan Pertambangan}

Lemahnya kewenangan yang dimiliki oleh pemerintah propinsi dalam mengelola sektor pertambangan di Propinsi Kalimantan Timur perlu untuk ditinjau kembali dengan memberikan kesempatan yang lebih besar pada pemerintah propinsi untuk memposisikan diri dalam berbagai aktifitas pertambangan di daerah ini. Kegiatan pertambangan sebagai suatu kesatuan dalam pengelolaan sumber daya alam merupakan potensi yang harus memberikan daya guna dan manfaat bagi pemerintah daerah mulai dari level kabupaten/kota maupun level propinsi. Porsi kewenangan yang begitu kecil bagi pemerintah propinsi untuk mengelola dan mengembangkan potensi sumber daya alam perlu untuk direposisikan kembali melalui suatu peraturan perundang-undangan yang nantinya akan menjadi kekuatan hukum bagi pemerintah propinsi dalam mengoptimalkan potensi yang dimiliki oleh masing-masing daerah. Posisi kewenangan propinsi yang hanya merupakan urusan pilihan perlu untuk dikembangkan menjadi urusan wajib sehingga daerah mempunyai kemampuan untuk mengatur dan mengembangkan wilyahnya masing-masing. Pemerintah pusat perlu untuk memperhatikan kekhasan suatu daerah dalam memberikan kesempatan untuk mengelola dan mengembangkan wilayahnya sesuai dengan kebutuhan daerah yang bersangkutan. Ragam kebutuhan yang berbeda antar daerah memungkinkan perbedaan jenis kewenangan yang dimiliki oleh daerah dalam mengelola dan mengembangkan potensi sektor pertambangnnya.

Fungsi pengawasan dari pemerintah propinsi baik secara langsung maupun tidak langsung menjadi hal yang begitu penting untuk dimaksimalkan oleh level pemerintahan. Hal ini terkait dengan posisi pemerintah pada level propinsi sebagai wilayah administratif yang memungkinkan berbagai urusan yang terkait koordinasi antar wilayah dapat dilaksanakan secara penuh.

Berjalannya fungsi pengawasan ini ditandai dengan semakin menguatnya posisi tawar dari level pemerintah propinsi dimata pemerintah kabupaten. Sehingga koordinasi antar wilayah 
dapat terbangun untuk mewujudkan pembangunan wilayah khususunya sektor pertambangan yang lebih baik dan terbangunnya konsep pembangunan sumber daya alam yang berkelanjutan.

\section{Pengelolaan Perkebunan}

Kalimantan Timur merupakan salah satu propinsi yang mempunyai prospek pada pengembangan sector perkebunan. Tanaman perkebunan yang dikembangkan di Kalimantan Timur antara lain: karet, kopi, kelapa, lada, cengkeh, coklat, kelapa sawit dan lainnya. Pembudidayaan tanaman perkebunan termasuk di dalamnya perkebunan besar pemerintah, perkebunan besar swasta, dan perkebunan rakyat. Dalam pengelolaan perkebunan supaya bisa berjalan maksimal diperlukan beberapa kewenangan yang bisa memayunginya. Dari beberapa kewenangan yang ada menimbulkan dinamika pada sector perkebunan di Kalimantan Timur. Berikut ini, beberapa kewenangan yang dimiliki pemerintah propinsi.

\section{a. K e w e n a ga n P e n g l o l a a n Perkebunan di Level Propinsi Berdasarkan UU Otoda}

No. 32 th 2004 tentang Pemerintahan

Daerah sektor perkebunan merupakan urusan pilihan di propinsi, bukan termasuk urusan wajib. Hal tersebut mengakibatkan kewenangan dari propinsi menjadi terbatas. Dalam pemberian izin pembukaan lokasi baru propinsi hanya mempunyai kewenangan pada level lintas kab/kota. Izin lokasi di kab/kota menjadi kewenangan dari bupati/walikota.
Kewenangan lain dari propinsi hanya berkutat pada kegiatan administrasi seperti pengembangan statistik dan sistem informasi perkebunan, memberikan tanda register pada usaha perkebunan, penyusunan peta pengembangan rehabilitasi, konservasi, optimasi, dan pengendalian lahan perkebunan, rekomendasi kesesuaian dengan rencana makro pembangunan perkebunan propinsi dari gubernur untuk Izin Usaha Perkebunan yang diterbitkan oleh Bupati/walikota, pengklassifikasian Kebun lintas kab./kota. Kewenangan pengelolaan sektor perkebunan menjadi perhatian dari pemerintah daerah karena sektor perkebunanan diharapkan menjadi salah satu solusi alternatif dalam memecahkan masalah rehabilitasi lingkungan akibat pengelolaan yang tidak memperhatikan keseimbangan ekosistem. M. Khusairi menyatakan bahwa : kewenangan pengelolaan perkebunanan seharusnya dititikberatkan pada level propinsi. Hal ini dimaksudkan agar fungsi koordinasi dalam pengelolaan lingkungan dapat memberikan manfaat bagi keseimbangan dan keberlanjutan ekosistem yang ada. ${ }_{6}$ Keterbatasan wewenangan yang dimiliki oleh dinas perkebunan menyebabkan penyelenggaraan fungsi koordinasi dan pengawasan dalam pengelolaan sektor perkebunanan oleh pemerintah propinsi dalam rangka mewujudkan pembangunan berkelanjutan juga terbatas.

${ }^{6}$ M. Khusiri dalam FGD sesi pertambangan, rektorat Unmul 2009. 


\section{b. Kendala yang Dihadapi Dalam Pengelolaan Perkebunan Pada Level Propinsi}

Sektor perkebunan yang hanya menjadi urusan pilihan pada level propinsi mengakibatkan terbatasnya ruang gerak propinsi dalam pengembangan sektor perkebunan di Kalimantan Timur. Dinas Perkebunan tidak mempunyai kewenangan untuk memberi dan mencabut izin.

Kewenangan diberikan kepada kab/kota, terkecuali untuk izin lintas kab/kota. Dengan dalih untuk mencapai target investasi dan pembangunan 1 juta ha sawit di Kaltim, banyak bupati/walikota yang mengobral memberikan izin. Tetapi sudah bertahun-tahun izin diberikan, ternyata tidak ada tanaman sawit yang ditanam, banyak lahan yang ditelantarkan. Hingga kini izin lokasi yang diberikan oleh Bupati/Walikota kepada para pengusaha Perkebunan Besar Swasta (PBS) mencapai 3.195.577 ha. Namun realisasi tanam baru 405.000 ha, itu artinya 2.790 .577 ha lahan dalam keadaan terlantar.

Pengembangan perkebunan di level Propinsi Kalimantan Timur terkadang juga terkendala dalam hal pengelolaan Hak Guna Usaha. Kawasan Budidaya Non Kehutanan (KBNK) yang sudah mempunyai Hak Guna Usaha sering terhambat dalam hal pengelolaan dengan Kehutanan. Pihak perkebunan tidak bisa melakukan penebangan kayu untuk membuka lahan tanpa izin dari kehutanan.

\section{c. Upaya Pemerintah Propinsi Dalam Mengoptimalkan Pengelolaan Perkebunan}

Khusus Propinsi Kalimantan Timur karena mempunyai potensi lahan yang sangat luas, ke depan sektor perkebunan bisa menjadi komoditi andalan seiring dengan semakin akan habisnya hasil tambang yang selama ini menjadi primadona dan hasil hutan yang semakin menipis karena banyak ditebang dan justru menimbulkan dan mengakibatkan banjir dan tanah longsor di Kalimantan Timur. Olehnya itu sector perkebunan yang sesuai amanat UU Otoda No. 32 tentang pemerintahan daerah menjadi urusan pilihan perlu menjadi urusan wajib. Pengawasan dan evaluasi (pelaksanaan kebijakan, norma, standar, kriteria, pedoman, dan prosedur di bidang perkebunan) selama ini menjadi kewenangan pemerintah pusat saja, sebaiknya propinsi juga diberikan kewenangan. Selain itu dalam pemanfaatan lahan perkebunan di setiap kab/kota perlu pelibatan propinsi dalam hal pengawasan dan evaluasi (hal tersebut bertujuan untuk meminimilisasi lahan perkebunan yang terlantar di kab/kota).

Izin lokasi yang bukan lintas kab/kota perlu koordinasi /pelibatan propinsi (kab/kota tidak seenaknya mengeluarkan izin). Selama ini ketika penggunanaan lahan di daerah kab/kota bermasalah baru melibatkan propinsi. Dalam hal ini diperlukan Memorandum of Understanding (MOU) antara gubernur dengan bupati/walikota seluruh Kaltim untuk mengawasi dan memberikan sanksi bagi Pengusaha Perkebunan Swasta (PBS) yang tidak mampu merealisasikan target tanam. Untuk menghindari lahan yang 
terlantar pemprop memerlukan kewenangan untuk memberikan pembatasan waktu maksimal dalam merealisasikan program tanam bagi pengusaha yang sudah mendapatkan izin.

$$
\text { Kendala dalam hal }
$$

pengelolaan Hak Guna Usaha yang sudah terbit terutama di Kawasan Non Budidaya Kehutanan (KNBK), memerlukan kewenangan penuh dari sector perkebunan untuk melaksanakan pengembangan lahan (tanpa campur tangan lagi kehutanan). Suatu areal yang sudah menjadi Kawasan Non Budidaya Kehutanan sebaiknya bidang kehutanan tidak lagi terlibat (bidang perkebunan tidak lagi meminta izin untuk menebang kayu) seperti yang terjadi selama ini. Dalam hal ini pemanfaatan Kawasan Non Budidaya Kehutanan bidang perkebunan perlu kewenangan khusus dari propinsi. Upaya lain yang perlu dilakukan adalah pembuatan sebuah rumusan yang tegas yang mengatur posisi structural antara pemerintah pusat, propinsi, dan kab/kota. Dalam bentuk negara kesatuan, betapapun pemerintah pusat harus tetap berada di puncak hierarki kewenangan yang dapat mengawasi setiap deviasi kebijakan perkebunan dan penyalahgunaan kekuasaan dari cabang pemerintahan di bawahnya, sambil pada sisi lain dapat menjamin terlaksananya maksud otonomi terutama dalam sector perkebunan. propinsi sebagai kepanjangan tangan pusat untuk mengawasi pelaksanaan kebijakan di kab/kota, sambil pada sisi yang lain sebagai simpul dari daerahdaerah yang menjalankan fungsi koordinasi dan sinkronisasi hubungan antar daerah.

\section{PENUTUP}

\section{Kesimpulan}

Berdasarkan uraian pada bagaian pembahasan, maka dapat ditarik beberapa kesimpulan :

- Lemahnya posisi pemerintah propinsi dalam pengelolaan sumber daya alam di Kalimantan Timur disebabkan lemahnya kewenangan yang dimiliki oleh pemerintah propinsi. Pengelolaan sumber daya alam merupakan urusan pilihan yang mengakibatkan sektor tersebut tidak mendapatkan perhatian yang lebih besar jika dibandingkan 16 kewenangan wajib yang dimiliki oleh pemerintah propinsi.

- Pengelolaan sumber daya alam lebih bertumpu di kabupaten/Kota sebagai urusan wajib dalam penyelenggaraan otonomi daerah. Hal ini menyebabkan lemahnya posisi tawar pemerintah propinsi terhadap pemerintah kabupaten/kota dalam pengelolaan sumber daya alam di wilyahnya.

- Pemerintah di level propinsi berupaya untuk mendapatkan kewenangan yang lebih besar dalam pengelolaan sumber daya alam melalui revisi undang-undang pemerintahan daerah dan perundang-undangan yang secara spesifik mengatur tentang pengelolaan sumber daya alam di level propinsi

\section{Rekomendasi}

Ter ka it de nga n m a i h ditemukannya beberapa kekurangan dalam pengelolaan sumber daya alam maka dirumuskan rekomendasi sebagai berikut :

- Perlu adanya perubahan terbatas pada UU No. 32/2004 tentang 
pemerintahan daerah, khususnya pasal 13 yang mengatur pembagian urusan pemerintahan yang terkait dengan urusan wajib dan urusan pilihan dalam pengelolaan sumberdaya alam. Pengelolaan sumber daya alam seharusnya dimasukkan menjadi urusan wajib pemerintah propinsi. Hal tersebut dimaksudkan agar pengelolaan sumber daya alam menjadi salah satu prioritas bagi pemerintah propinsi.

- Perlu memperhatikan potensi sumber daya alam yang khas di suatu daerah seperti ; potensi hutan, tambang dan perkebunan, sehingga kewenangan pengelolaan yang diberikan nantinya tepat sasaran dan mampu menghindari konflik kepentingan di dalamnya.

- Perlu adanya kewenangan yang lebih tegas/nyata pada pemerintah propinsi dalam pengelolaan sumberdaya alam di daerah, khususnya dalam pemberian izin dan penentuan wilayah pengelolaan yang melewati batas administratif kabupaten/kota. Sementara kabupaten/kota hanya pada posisi pelaksana teknis dalam hal pelaksanaan dan pengawasannya.

- Perlu kajian lebih lanjut tentang pelaksanaan fungsi koordinasi antara pemerintah kabupaten/kota dengan pemerintah propinsi dalan penyelenggaraan urusan pemerintahan di daerah khususnya pengelolaan sumber daya alam di Propinsi Kalimantan Timur.

\section{DAFTAR PUSTAKA}

A b d u l Wah a b, S oli chin. 1997. Kebijakan Pembangunan
Pedesaan Di Negara-negara

Berkembang, skala

Permasalahan dan

Hekekatnya. Dalam Kebijakan

Publik dan Pembangunan.

Malang: IKIP 2002. Analisis

Kebijaksanaan Dari

Formulasi Ke Implementasi

Kebijaksanaan Negara .

Jakarta: Bumi Aksara.

Bratakusumah, Supriady, Dedi dan Solihin, Dadang. 2001.

Otonomi Penyelenggaraan

Pemerintah Daerah. Jakarta:

Gramedia Pustaka Utama.

Dwi Susilo, Rachmad K. 2008.

Sosiologi Lingkungan. Jakarta:

Raja Grafindo Persada.

D. Siregar, Doli. 2002. Optimalisasi

Pemberdayaan Harta

Kekayaan Negara. Jakarta:

Gramedia Pustaka Utama.

Islamy, A.Irvan. 1994. Prinsip-prinsip

Perumusan Kebijakan

Negara, Jakarta: Bina Aksara.

Edisi 2, Cet. 1.

Kaho, Josef Riwu, 1991. Prospek

Otonomi Daerah di Negara RI.

Jakarta: Rajawali Press.

$\mathrm{K}$ ar to d ih ar d jo, $\mathrm{H}$ ar iad i. 2006 . Pengelolaan Sumber Daya Alam (PSDA) di P. Jawa dalam Perspektif Otonomi Daerah.

Bahan Diskusiyang dilaksanakan Koalisi LSM

Jawa Timur di Surabaya, 29

November 2006 . Dalam

http://repository.ipb.ac.id/bitst ream/handle/123456789/4192 $3 /$ pengelolaan $\% 20$ sumber $\% 2$ 0daya $\% 20$ alam $\% 20 \% 28 P S D$ A\%29di\%20p.jawa\%20dalam $\% 20$ perspektif\%20otonomi\% 20Daerah.pdf?sequence $=1$ 
OTONOMI DAFRAH DAN PENGEL OLAAN SUMBER DAYA ALAM DI PROVINSI KALIMANTANTIMUR (STUDI KASUS KEWENANGAN PENGELOLAAN KEHUTANAN, PERTAMBANGAN DAN PERKEBUNAN)

diakses 14 Februari 2012.

Keraf, A. Sonny. 2006. Etika

Lingkungan. Jakarta: Penerbit

Buku Kompas.

Mazmanian, Daniel and Paul A.

Sabatiar (eds), 1988. Effectivly

Policy Implementation.

Lexington Mass

Meter, Donald, S. Van dan Carl E. Van

Horn. 1975. The Policy

Implementation Process;

Aconceptual Frame Work,

Beverly Hills: Sage

Publication Inc.

Milles, B. Matthew dan A. Michael, Huberman. 1992. Analisis

Data Kualiatif . Jakarta:

Universitas Indonesia.

Moleong, Lexy J. 2006. Metodologi Penelitian Kualitatif Edisi Revisi. Bandung. Remaja Rosdakarya.

Nazir, Moh.1999. Metode Penelitian. Jakarta. Ghalia Indonesia.

Sabar, Eko Prihatin. 2009. Otonomi Daerah dan Pengelolaan Sumber Daya Alam. Semarang: Fakultas Hukum Universitas Diponegoro,

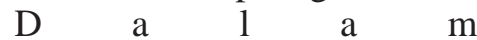
http://senatorindonesia.org/se nator/UPLOADED/files/UND IP otonomi\%20daerah\%20da n\%20pengelolaan\%20SDA.p df. Diakses 14 Februari 2012.

Santoso, Purwo, Mencari Keterpaduan Ekosistemik dalam Pengelolaan Sumberdaya Alam di Daerah, Makalah disampaikan dalam "Seminar Internasional IV Dinamika Politik Lokal di Indonesia: Partisipasi dan Demokrasi”, Salatiga, 14-18 Juli 2003.
Soemarwoto, Otto. 2001. Analisis Mengenai Dampak Lingkungan. Yogyakarta: Gadjah Mada University Press.

Subarsono, A.G. 2005. Analisis Kebijakan Publik. Yogyakarta: Pustaka Pelajar.

Sugiono. 2008. Metodologi Penelitian Kuantitatif Kualitatif Dan $R \& D$. Bandung: Alfabeta.

Suharto, Edi. 2005. Membangun Masyarakat Memberdayakan Rakyat. Bandung: Refika Aditama. .2005. Analisis Kebijakan Publik. Bandung: Alfabeta. . 2007. Kebijakan Sosial

Sebagai Kebijakan Publik. Bandung: Alfabeta.

Supamoko, M. 2006. Ekonomi Sumber Daya Alam dan Lingkungan (Suatu pendekatan Teoritis). Yogyakarta: BPPE.

Utomo, Tri Widodo W. 2007. Menerawang Pembangunan Wilayah di Masa Depan Dengan Analisis Skenario (Scenario Planning). Samarinda: PKP2A III LAN.

Winarno, Budi. 2007. Kebijakan Publik Teori \& Proses . Yogyakarta: Media Pressindo.

Yasmi, Yardi. Dkk. 2005. Kompleksitas Pengelolaan Sumber Daya Hutan di Era Otonomi Daerah; Studi Kasus di Kabupaten Sintang Kalimantan Barat. Bogor: Inti Prima Karya. Dalam http://www.cifor.org/publicati ons/pdf_files/Books/BYasmi0 601.pdf diakses 14 Februari 2012.

Kompas, 4 Mei 2007. 